\title{
"This Research That We Are Doing Is Just the Beginning of the Conversation": Undergraduate Researchers Enacting Literacies of Relationality
}

Vaughn W. M. Watson, Department of Teacher Education, College of Education, Michigan State University

Rae L. Oviatt, Assistant Teaching Faculty, Wichita State University

Terry Flennaugh, Department of Teacher Education, College of Education, Michigan State University

Chauntel Byrd, Michigan State University

Regina Deloach, Michigan State University

Sarah Jackson, Michigan State University

Jewel Pugh, Michigan State University

We extend theoretical perspectives of critical listening and storying with undergraduate researchers of Color as they conducted a Youth Participatory Action Research inquiry. Undergraduate researchers designed, analyzed, and shared findings of their photovoice project examining their transition experiences to a PwI. We asked: what literacy activities do undergraduate researchers of Color enact during the photovoice project; and how are undergraduate researchers' literacy activities shaping and, in turn, shaped by contexts of relationality? We conceptually frame our work as extending notions of quilting across African Diaspora women's communities. We discuss how undergraduate co-researchers enact literacies of relationality 
while examining transition experiences of first-year students of Color. This stance-taking considers how educational communities including teachers, teacher educators, education researchers, and student affairs educators may meaningfully incorporate knowledge, perspectives, and questions of preservice teachers of Color, which are an integral part of transition experiences of undergraduate researchers and future teachers.

On a Monday night in September, we ${ }^{1}$ gathered in New Perspectives Gallery, an arts exhibition space on the northeastern edge of campus where Terry and Vaughn are faculty, Rae is a doctoral student, and Chauntel, Regina, Sarah, and Jewel are undergraduate researchers and students in a teacher-preparation program. Six weeks before, Rae had arranged with the gallery curator to show our one-night exhibit of photographs taken during a photovoice project in our Youth Participatory Action Research inquiry examining transition experiences of first-year students of Color to a predominantly white institution (PwI).

As we entered the gallery and set photographs on easels, artifacts remained from the previous exhibit of a collection of quilts. One artifact was a credit panel explaining a quilt titled "Freedom Day" - described by the artist as intended to "tell stories that describe various experiences and aspects of people's lives and of notable events by way of visual display" (see Figure 1). These quilts, and the notion of quilting, conceptually frame the critical listening and storying (San Pedro et al., 2017) we engaged in our designing, enacting, and sharing of the experience of our photovoice initiative.

This article seeks to extend theoretical perspectives of critical listening and storying with undergraduate researchers of Color as they conducted a Youth Participatory Action Research (YPAR) inquiry. Undergraduate researchers designed, analyzed, and shared findings of their photovoice project examining their transition to a PwI. We call attention to these literacies of relationality - relational and pedagogical activities and approaches that build with lived experiences of

1 "We" refers to Vaughn, Rae, Terry, Chauntel, Regina, Sarah, and Jewel. 
undergraduate research collaborators; and to the importance of affirming literacy activities shaping and shaped by contexts of relationality in the transition experiences of the undergraduate students. This stance-taking considers how educational communities including teacher educators, education researchers, and student affairs educators may meaningfully incorporate knowledge, perspectives, and questions of undergraduate researchers, which are an integral part of their transition experiences.

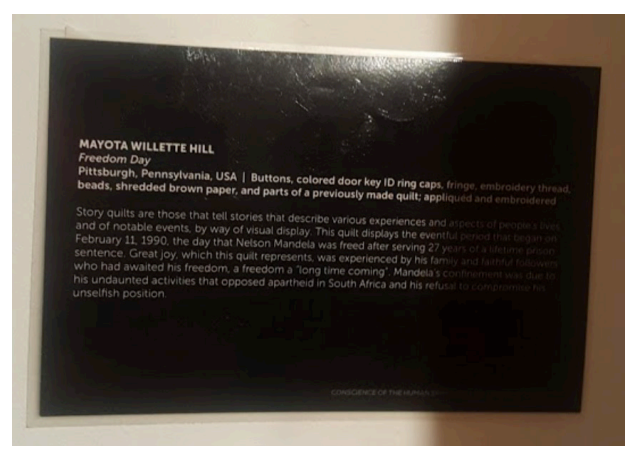

Figure 1. Credit panel describing the "Freedom Day" quilt.

\section{Undergraduate Preservice Teachers of Color and the Urgency of Relationality}

In contextualizing our work, we build with researchers examining college orientation, transition, and retention experiences of undergraduates including future teachers of Color (Kohli, 2009; Yao et al., 2019). For example, Kohli and Pizarro extended Wilson's (2008) framings of relationality, and called attention to hierarchical and colonial structures of formal schooling contexts, underscoring the urgency of models of mentoring that include community-oriented perspectives for early-career teachers of Color. Kohli and Pizarro (2016) noted that teachers of Color who seek to be of service with youth and families intentionally position themselves in work with communities of Color. Such contextualizing of relationality is urgent at a time when U.S. public-school teachers are primarily suburban, middle-class white women, and students are increasingly racially, ethnically, and linguistically diverse.

We furthermore understand the importance of relationality given contexts of campus racial climate and racial microaggressions (Solorzano et al., 2000), an increased "matriculation gap" underscored by lack of representation of youth of Color on campus (Eberle-Sudre et al., 2015), and opportunities to support students of Color given socioeconomic and 
racial diversity (Park et al., 2013). Specifically, in the context of college orientation, transition, and retention, Shelton and Thompson (2020) analyzed experiences of three Puerto Rican students after Hurricane Maria as the students navigated the transition to higher education. The authors examined how a higher-education institution "fostered resilience for displaced and non-displaced students transitioning to navigating college" (p. 1). Undergraduate participants discussed possibilities for student affairs educators to engage "proactive outreach" toward "creating community and demonstrating care for individual student circumstances" (p. 1). Rust and Korstange (2018) found benefits for students participating in first-year seminar courses through "prioritizing reflection and integrative learning" (p. 76).

Morgan et al. (2020), in a study examining the "orientation and transitional experiences" of Black undergraduate students attending a public research university in an urban setting, found that participants observed a "shortage of Black faculty, limited Black cultural programming, and a need for identity-based space" (p. 1). Morgan and colleagues identified implications for "orientation professionals" including "recruiting professional and student staff members who represent the racial composition of the university and ensuring culturally relevant content during orientation programs" (p. 1). Yao et al. (2019), studying experiences transitioning to higher education institutions in the US by international students of Color, emphasized the importance of "social support" (p. 17), and faculty and student affairs assistance in academic study and transition, including peer mentoring.

In framing literacies of relationality in participatory research that builds with the lived experiences of undergraduates of Color, we furthermore assert the significance of intergenerational mentoring among faculty and undergraduates of Color (Dingus, 2008), particularly within PwI spaces. Villaseñor et al. (2013), for example, conceptualized possibilities for mentoring for Chicanas/Latinas in the context of college student retention as the interplay of "the academic, professional, and the personal in a culturally specific framework in order to create more meaningful and enduring mentoring relationships" (p. 49). Such stance- 
taking in teaching, teacher education, educational research, and with student affairs educators emerges as a necessary next step in the long and continuous movement toward equitable access to schooling for students of Color. Thus, we asked as overarching research questions: what literacy activities do undergraduate researchers of Color enact during a photovoice project in a Youth Participatory Action Research (YPAR) ${ }^{2}$ study examining transition experiences of undergraduates of Color to a PwI?; and how are undergraduate researchers' literacy activities shaping and, in turn, shaped by contexts of relationality?

\section{Conceptually Framing These Quilts, and This Quilting}

In calling attention to literacies of relationality as examples of critical listening and storying, we evoke the conceptual framework of quilting circles. In this way, we situate the participatory research activities of our research team - two faculty members who are Black men, four undergraduate students who are Black women, and one graduate student who identifies as a white-presenting woman (Johnson, 2019) - within histories of literacies created and nurtured with and by Black women (Barkley Brown, 1989; Haddix et al., 2016; Ringgold, 1996). We frame literacies of relationality through the lensing of quilts composed to communicate meanings and messages across African Diaspora women's communities to purposefully assert conceptual frames beyond Eurocentric lenses (Paris \& Alim, 2017; Watson \& Knight-Manuel, 2017; Watson \& Knight-Manuel, 2020). Moreover, viewing literacies of relationality through the conceptual frame of quilting calls attention to what we mean by envisioning community in the collaborative design, enacting, and public sharing of our YPAR inquiry examining transition experiences. We envision ourselves as participatory co-researchers for whom our lived experiences prompted continuous conversation comprised of multiple perspectives (Soep, 2006). We thus envisage in the folds of our work, as readings and renderings of these quilts, how teachers, teacher educators, educational researchers, and student affairs educators may meaningfully

${ }^{2}$ We take up Caraballo et al.'s (2017) defining of "youth" in YPAR as inclusive of "elementary school age to undergraduates in college" (p. 331). 
attend to heart-engaged research as not solely the research under study but the work of research, enacted.

\section{Theoretically Framing Literacies of Relationality}

We analyze literacies of relationality through lenses in dialogic conversation (Kinloch \& San Pedro, 2014) - conceptually framing quilting as stance-taking, and theoretically extending perspectives of critical listening and storying.

San Pedro et al. (2017) theorized "critical listening and storying" in reflecting on a collaborative discussion group with high-school youth in a course titled Native American Literature. In critical listening and storying, San Pedro and colleagues asserted, "realities (and truths) can be found in a particular location and time and delivered through the exchange between telling and hearing of our stories" (p. 670). In our inquiry, critical listening and storying unfolded as an integral component of forming, sustaining, and extending literacies of relationality. These moments, of critical listening and storying each other and ourselves across teaching and research spaces, emboldened opportunities for humanizing connections in sharing individual and collective stories of transition experiences, for coming to know one other and our research (Kinloch \& San Pedro, 2014; Kirkness \& Barnhardt, 1991; Wilson, 2008).

Mirra et al. (2015b) similarly observed that YPAR inquiries pointedly engage participants across "pedagogies of relationships" (p. 36). Marciano and Watson (2017), for example, discussed how pedagogies of relationships developed in a qualitative study of youths' creative and artistic literacy practices as "youth negotiated roles of engagement with each other, with Vaughn, and across research processes" (p. 75). As an approach in adolescent literacy teaching and research, Wissman et al. (2015) called attention to "research pedagogies" of "created spaces, engaged participation, and embodied inquiry" (p. 186) across adolescents' multimodal literacy activities. Relationality and the building of reciprocal teaching and learning in our research collaboration unfolded as connective threads across the design, enactment, and public sharing of a photovoice project that had its beginnings in a for-credit summer bridge program, and 
extended across more than two years of weekly research-team meetings involving the examination of undergraduates' transition experiences (Morgan et al., 2020; Rust \& Korstange, 2018).

\section{Contextualizing Literacy Practices and Teacher Education within our YPAR Inquiry}

Scholars have highlighted the research literacy skills and liberatory possibilities of participant research with adolescent youth and young adults (Bautista et al., 2013; Cammorata, 2008). Moreover, researchers have asserted the urgent work of students writing in ways both praising and critiquing places that youth and young adults understand as meaningful (Watson \& Beymer, 2019). Kinloch (2009) for example, analyzed how students in an undergraduate writing course "create written responses on the politics of place" (p. 154). Such work prompts a rethinking of literacies of relationality as possibilities of writing and reflecting on transition experiences across educational and community contexts, include contexts of undergraduate writing and learning.

In considering more fully undergraduate researchers who are future teachers of Color as knowledge holders of their own university experiences, we thus sought to enact participatory research on transition experiences that compels "a commitment to collaboration, participant knowledge, and action” (Mirra et al., 2015a, p. 50). Bennett et al. (2006) further highlighted benefits of participatory research with undergraduate preservice teachers of Color in an initiative that saw student matriculation rates increase by about $50 \%$, and $80 \%$ of participants continuing to teach in public schools. Yet less YPAR work has been conducted within teacherpreparation programs (Anderson et al., 2015). Moreover, fewer studies center the need for addressing transitions and retention of teachers of Color in teacher-preparation programs through enacting participatory teaching and learning approaches. The current inquiry provides valuable insight into relational and pedagogical activities and approaches situating preservice teachers of Color as knowledge holders in examining issues endemic to their educational experiences, including transition experiences. 


\section{Modes of Inquiry}

In considering critical listening and storying as an unfolding of literacies of relationality, the research team comprised of faculty, a graduate student, and undergraduate co-researchers traces the beginnings of our relational work to teaching and learning in a summer bridge program in 2016.

\section{Contextualizing the Research Inquiry}

Chauntel, Regina, Sarah, and Jewel were enrolled that summer, before the first fall semester of their undergraduate year, in a critical multicultural education course taught in the bridge program by Terry. The course included a service-learning field experience. We understand service learning as long used to provide preservice teachers' opportunities for critical reflection and exposure to inequity in institutions and communities (Holsapple, 2012). Yet challenges of service learning include attention to preparation, reflection, and connection to course readings that may prompt unintended consequences of reinforcing deficit-oriented beliefs about marginalized communities (Mitchell \& Donohue, 2009). Moreover, preservice teachers of Color, and notably those from urban communities, often participate in service-learning experiences predicated on white norms (Milner, 2003).

Given this context of service-learning experiences, a growing scholarship considering how teacher-education models may meet unique needs of preservice teachers of Color (Rogers-Ard et al., 2013), and access, retention, and transition scholarship involving students of Color (for ex., Carey, 2019; Flennaugh et al., 2017; Howard et al., 2016; Knight et al., 2019; Morgan et al., 2020; Yao et al., 2019), Terry in spring 2016 proposed a redesign of the service-learning field experience for the summer 2016 critical multicultural education course. Specifically, Terry, Vaughn, and Rae redesigned the service-learning experience as a YPAR inquiry, to begin in fall 2016. 


\section{Data Collection and Analysis}

Terry, Vaughn, and Rae, and six first-year women of Color met each Tuesday that fall semester, collaborating on the YPAR inquiry. (Four of the six undergraduate students - Chauntel, Regina, Sarah, and Jewel continued into spring 2017). From the start, we referred to ourselves as a research team, and to our sessions as research-team meetings. Beginning a practice we came to understand as an integral component to critical listening and storying, and orientation and transition experiences, Terry opened each research-team meeting with a "check-in" (Edwards et al., 2014, p. 433; Rust \& Korstange, 2018). We then engaged a range of teaching and research activities across the semester.

For example, in our first week, Terry, Vaughn, and Rae referenced research literature that Chauntel, Regina, Sarah, and Jewel had read and discussed as participants in the critical multicultural education course in the bridge program (i.e., Freire, 2018; Sensoy \& DiAngelo, 2012). Key questions in the course had included: "In what ways do schools create, perpetuate, and exacerbate inequality?"; and "what does it mean to teach for social justice in urban environments?" In discussing course readings in this new context of the YPAR inquiry, the research team sought to design and enact participatory research as a way of putting to work critical theories and pedagogies involving action toward social change. For instance, teaching and research activities in Weeks 1 and 2 involved the research team collectively composing definitions on chart paper of "youth" and "research," and in Week 3, we drafted and revised a list of assets within and across the campus community that undergraduate researchers noted as important to them (YPAR Hub, 2015).

In Week 4, we began drafting our research question, enacting an inquiry stance we later discussed as negotiated questioning (Oviatt, Watson, \& Flennaugh, 2020). This work involved formulating a research question across the lived experiences of undergraduates of Color and key questions on race and racism, social inequality, power, and social institutions with which undergraduates had tussled in the critical multicultural education course in the summer bridge program (Covarrubias et al., 2018). Specifically, we posed as research questions 
for the YPAR inquiry: What are the transition experiences of first-year students of Color to a PwI; and, how do transition experiences of first-year students of Color inform (and are informed by) issues of campus climate? Starting in Week 5, Vaughn, Terry, and Rae introduced the undergraduate researchers to data-collection methods, and across the fall semester the full research team designed a plan for data collection and analysis.

Initial data collection. To examine the YPAR inquiry research questions, we collected a range of data in the spring 2017 semester, including ethnographic field notes and analytic memos. We administered a survey, conducted interviews, and facilitated a photovoice project.

Field notes and analytic memos. Each week, an undergraduate researcher joined Rae and Vaughn in typing ethnographic field notes in a Google Doc shared with the full research team, detailing teaching and research activities. Analytic memos were also written following researchteam meetings.

Surveys. Terry and Jewel designed a survey to gain a snapshot of transition experiences of first-year students of Color to a PwI, asking questions about experiences of campus climate; and social, academic, financial, professional, health-and-wellness, arts-and-culture, and diversity transitions. For instance, we asked "How well do you think different ethnic groups understand one another on campus?", and if students "feel like I am a part of a community while on campus."

We recruited survey participants through personal contacts, and a flyer emailed to coordinators of organizations offering events or activities involving students of Color, such as the Black Student Alliance and Culturas De Las Razas Unidas. Chauntel, Regina, Sarah, and Jewel also took turns sitting at a table near the entrance of a large dining hall to recruit participants. We administered the survey to 36 first-year students of Color, including Chauntel, Regina, Sarah, and Jewel. We understood Chauntel, Regina, Sarah, and Jewel as simultaneously undergraduate researchers and research participants, an enacting of what Caraballo et al. (2017) asserted as "inherent fluidity between teaching, learning, and coresearching in YPAR" (p. 323), and underscoring the interplay of critical listening and storying as instances of relationality in examining our transition experiences. 
Interviews and a photovoice project. To conclude the survey, we asked undergraduates to indicate their interest in participating in an individual interview, focus-group interview, or photovoice project. We emailed an invitation to participate to survey respondents who indicated interest.

Regina, assisted by Vaughn, designed interview questions to further explore survey questions, and undergraduates' experiences of transition. For example, we asked: "[The university] has a student population of over 50,000 students. How, if in any way, has the campus made you feel more connected to the university?" Regina then conducted individual interviews with four participants, each lasting about 90 minutes, and wrote analytic memos following interviews.

Initial data analysis. We understand data collection, analysis, and interpretation as iterative, and informing further collection, analysis, and interpretation. Initial analysis therefore involved the research team, as first-cycle coding method, using descriptive coding (Saldana, 2015) to summarize, in keywords, the collected data. For example, we identified that first-year students of Color considered ethnic groups as tight knit with each other. In seeking to learn with transition experiences of undergraduates of Color to a PwI, we then asked analytic questions of the data, with Chauntel, Regina, Sarah, and Jewel seeking to examine: "where are you now?" in your story of transition; "what do you wish to change?"; and "what's next as the 'end' of the story?" of your transition to a PwI. As site of critical listening and storying, and an enacting of literacies of relationality, the YPAR research team then designed and enacted a photovoice project to examine our research questions and analytic questions through the perspectives of first-year students' photographs of their experiences of transition.

Ongoing data collection: the photovoice project. Scholars have called attention to limitations of photovoice in documenting participants' lived experiences (Prins, 2010). Yet we understood youth co-researchers using photovoice - telling stories through taking and discussing photographs - as enacting work that Greene et al. (2018) asserted as "call[ing] attention to social problems that may not be visible to many 
adults" (p. 846). Moreover, the photovoice project reflected the work that Roegman and colleagues (2016) discussed of student researchers who may "come to understand and enact their positionalities in research, especially in relation to data analysis, interpretation, and representation" (p. 44). Specifically, Roegman et al. called attention to how "doctoral students positioned themselves, and how their positioning shifted, as they moved from reading about positionality in coursework to doing work around positionality in a [culturally sensitive research] project" (p. 44). Similarly, in our inquiry, doing the work of critical listening and storying, as an unfolding of literacies of relationality, involved Chauntel, Regina, Sarah, and Jewel participating in the photovoice project examining their experiences of transition as first-year students of Color to a PwI.

Rae and Sarah designed the photovoice-project protocol, drawing directly from analytic questions the YPAR research team developed and asked during initial analysis of the collected data. Then, for three consecutive weeks in spring 2017, Chauntel, Regina, Sarah, and Jewel used mobile phones to each take photographs or gather screenshots of five to 10 images in conversation with a three-part arc of a story of their experiences of transition. Chauntel, Regina, Sarah, and Jewel also wrote a narrative caption to accompany each cell phone photograph or image.

Therefore, in the first week, images and captions reflected the beginning of their first year and responded to the prompt, "where you are now." The next week, Chauntel, Regina, Sarah, and Jewel in images and captions considered the middle of the year - "what do you wish to change" - in their story of transitioning to a PwI. Then, images and captions reflected "what's next as the 'end' of the story" of your transition to a PwI; "what is out there to support you?"; and "what would you want to see added?"

Ongoing data analysis: the photovoice project. Chauntel, Regina, Sarah, and Jewel each shared print outs of their images and captions in research-team meetings. Data analysis as critical listening and storying next involved research team members engaging multiple rounds of analysis. First, we grouped photographs into categories, such as "black and white" or "nature." We then discussed similarities and differences 
of experiences of transitions based on photos. We then named recurring patterns such as "personal reflection" and "identity," and we selected a subset of eight photographs to examine further for content and thematic meanings.

As analysis procedure for the eight photographs, Chauntel, Regina, Sarah, or Jewel introduced their photographs in a sentence or two, and the full YPAR research team discussed our initial noticings. We next posed content-analysis questions of each photograph. For example, we asked, "What might we say about the setting, spaces, places, [and] time noted in this photo?"; adapting Ray and Smith (2012), we asked, "what does the 'layout of the picture' suggest?" (p. 302), and "in this photograph, what might we say about 'the activities undertaken' or not undertaken?" (p. 302). We then analyzed each photograph for thematic meanings, asking what "key issues, patterns, connotations, and denotations" are suggested in this photo? (p. 303). We compiled noticings, content analysis, and thematic analysis in a shared Google Doc. In conversation with our analytic questions, and with the photograph of a poem shared by Regina, we named "Don't Quit" as overarching theme of transition experiences of undergraduates of Color, rendered in the photovoice project.

\section{Findings \& Discussion}

While Terry, Vaughn, and Rae had initially designed the YPAR inquiry as a one-semester service-learning field experience following the summer bridge program, we continued our YPAR research-team meetings into the next academic year, fall 2017, as undergraduate researchers, now college sophomores, navigated new classes, social, and work activities. As a rendering of critical listening and storying, and enacting of literacies of relationality, Chauntel, Regina, Sarah, and Jewel shared findings that October of their research on experiences of transition to a PWI, in the public space of a YPAR symposium co-organized by a Black faculty member on our university campus (Morgan et al., 2020), and attended by youth researchers from middle and high schools across the state. Three weeks before that, we had gathered in New Perspectives Gallery for the exhibit we noted in opening this manuscript, where Chauntel, Regina, Sarah, and Jewel placed one photograph each on an easel, and we 
projected onto the screen stretched across one of the gallery walls the photographs taken and captions written during the photovoice project (see Figure 2).

We understand this sharing of research findings - words, music, photographs and captions displayed amid artifacts of quilting from a previous gallery exhibit, as conceptually framing our theorizing of literacy activities as literacies of relationality. We thus note as interconnected points in our rendering of transition experiences of undergraduates of Color, as patterns of a quilt, the urgency of building with lived experiences of collaborators, the enacting of heart-engaged research that cultivates fam, and an honoring of ever-present connections.

Six weeks after the gallery exhibit, we continued the public sharing of research findings that would become this manuscript in a roundtable presentation attended by middle and high-school English teachers, graduate students, and university faculty in literacy and English education at the National Council of Teachers of English (NCTE) annual meeting in St. Louis, Missouri. Chauntel, an undergraduate co-researcher, later wrote in a research memo, "We recall feeling regarded as valued knowledge holders, as a doctoral student attending our roundtable asked us questions and inquired about our methods and approach taken up during our research." A year later, we returned to NCTE in Houston, Texas. We read excerpts of this manuscript alongside two teams of faculty authors sharing findings of YPAR inquiries at their universities, further reflecting and learning on a panel presentation on experiences across our first year (Rust \& Korstange, 2018).

We continued the collaborative journey, and critical listening and storying, into the spring, 2019, semester, six semesters after we first met 
on a Tuesday in a research-team meeting. The research team including undergraduate researchers, now university juniors, gathered a 15-minute drive from the college campus. We ordered chicken and waffles, candied yams, and mac and cheese at the restaurant that feels like home, named for its owner, a Black man whose family has lived in the state's capital city since 1880 (Dozier, 2018), and we sat for family dinner. We call attention to this quilting, this ongoing weaving of data collected and analyzed as we move across designing, drafting, revising, and sharing our inquiry of experiences of transitions to a PwI for undergraduates of Color with new audiences, across this space of a journal article.

In rendering meanings of transitions to a PwI, and given the prevalence of photovoice in our data analysis, we provide examples of first-year students' photographs and captions composed in the photovoice project. Additionally, we write across excerpts of undergraduate researchers' reflections of their transition experiences in research memos, and undergraduate researchers' analysis of the photovoice inquiry written as Chauntel, Regina, Sarah, and Jewel contributed to drafts of this manuscript. Importantly, Chauntel, Regina, Sarah, and Jewel expressed similarities and differences across their lived experiences as urgent starting points in "prioritizing reflection" (Rust \& Korstange, 2018, p. 76) of first-year experiences of college orientation, transition, and retention. As Rae and Chauntel wrote in an earlier manuscript draft:

Most importantly, this work moves away from a monolithic understanding of Black women's experiences transitioning to a PwI (Amoah, 1997; Collins, 2000). We (youth co-researchers) identify as four African American women building a story about our first year transition to a PwI. We are all very different and offer different dynamics to the group.

We thus author as quilt panels an unfolding of literacies of relationality, threaded across an analysis of experiences of transition.

\section{Quilt Panel 1: Building With Lived Experiences of Collaborators}

In an analysis of a photograph taken during the photovoice project (see Figure 3), Regina wrote: 
I photographed my

dormitory bed, intentionally

framed by images reminding me where I came from:

a case of water bottles

unopened, a poem that

reckons with meanings of

resilience, and stars, tilted

upward, that reflect my

passion to rise. These points

work together to render an

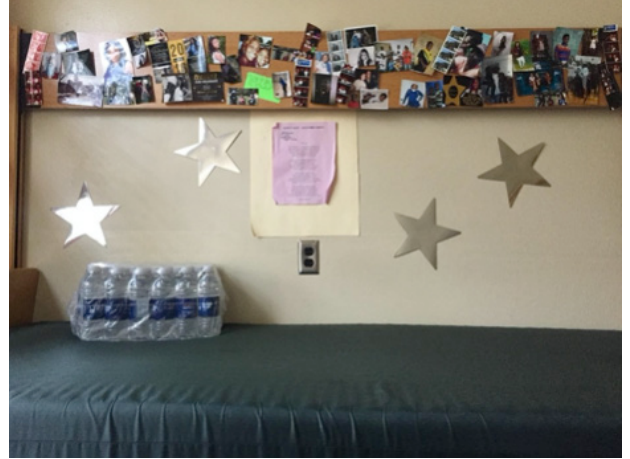

Figure 3. A photovoice photograph taken by Regina. image that sings my lived experience. Staging and taking this photograph offered forward, as I wrote in the narrative caption accompanying the photo for the photovoice project, "a reminder of going back home for the summer." Thinking of my hometown of Flint, I shared, "they are with me right now."

In examining content and thematic meanings of the photograph, Regina noted that she intentionally set the case of water on the bed prior to taking this picture. She reflected that the photograph thus offered forward a "reminder" of returning home, important in prompting Regina to recall her hometown of Flint, Michigan, and the Flint water crisis (Green, 2019). As Regina shared, "this is with me right now; Flint is with me." Regina further noted:

A lot of people forget about the city of Flint. [...] I didn't have anything about Flint in the first round of photos [...] and that was really important to me because I was the only one from Flint in the research.

For Regina, the ongoing state of environmental and racial injustice continuing to affect Flint and its working-class communities, with residents primarily of Color, holds meaning in how she considers herself in ways as defined by and defining place, and how she contextualizes her future aspirations (Green, 2019). Regina in (re)considering meanings of home and the university campus expands on a notion of resilience in the context of "creating community and demonstrating care" (Shelton 
\& Thompson, 2020, p. 1). Namely, Regina grapples with the desire she has to continue to be reminded of and complicate what may be meant by resilience, in the poem bordered on the wall with gold stars and titled in boldface "DON'T QUIT - KEEP DREAMING."

Regina shared that in the space of the university campus, "Flint is with me, in how I seek to be genuinely successful, as first in my family to go to college" and the oldest of her mother's children. In that way, family and friends are rendered present, affixed to the bedframe above the "Don't Quit" poem, alongside new experiences on campus.

Writing in a caption, Regina pointed to two items visible in the photograph pinned above the "Don't Quit" poem - "cards made for me by students in my role as resident assistant, and all of the letters I received as 'RA of the week,' where undergraduate peers shared that 'I was kind,' and 'I really enjoy my job."' Across images and captions, Regina underscored her emerging leadership role in the more recent context of the university campus, and the familiar space of her hometown: "These photographs and experiences reflect [...] what potential my future holds to inform the future of my city, especially as a leader within my family." Regina recalled, as she analyzed her photograph for content and thematic meanings:

I remember that green card is the letter my mother wrote for ESS [the Early Student Success transition program for admitted firstyear students]. [The program coordinator] had the parents write our greatest fear and our greatest hope [...] and I think I put the hope side up.

Regina further noted in her caption of more wistful meanings of home: The pictures of my family are very motivational, a lot of my friends, and pictures of my senior year [...] But these photos of where they are now I barely even look at them [...] only when they fall [off the wall]. The majority of them are in my drawer and they have been in my drawer for a while. [...] Sometimes I feel out of touch with my city for being up here [...] My motivation has changed.

\section{Quilt Panel 2: Moving From Collaborators to Fam}

Chauntel in a research memo reflected on an interplay of "social 
support" in engaging academic work amid experiences of transition (Yao et al., 2019, p. 17), and identifying an "identity-based space" (Morgan et al., 2020, p. 1) for Black undergraduates at a PwI. Chauntel wrote:

I think often times I question my scholarly abilities because of my identities. Sometimes this little inclining of doubt especially attending a PwI gets triggered. This doubt has grown less and less over the past year because I have realized that when doubting myself I implant this idea of fear. Someone once told me to look at fear as an acronym, "F.E.A.R.," therefore F.E.A.R is false evidence appearing real. [...] I have proven it over and over again to myself and others because I am still here at the PwI. This has made me open my eyes that when I write a paper I have to be more complex through boosting up writing. Presenting at New Perspectives Gallery, the symposium, and the [NCTE] conference, it's made me more comfortable talking to people. The space that we've created, it's easier to talk because I can relate to you guys and you guys can relate to me. If I am presenting in class to all white people, I have that inkling of insecurity that people won't get me because of the color of my skin or what I have to say. Because they are complete strangers.

Chauntel, reflecting in her research memo on learning across first-year experiences (Rust \& Korstange, 2018), additionally wrote:

In this way our collective research work has provided opportunities for me to not only envision myself as a scholar, but to exist as a scholar. This noting is in sharp juxtaposition to my earlier mention of myself as having 'doubt' about performing academically at a PwI, especially given the national conference presentation was specifically in a research strand, a space typically held for those with much longer academic careers behind them.

The collective work of the research team provided Chauntel opportunities for academic affirmation, and a place of comfort (Shelton $\&$ Thompson, 2020). She notes, "I can relate to you guys and you guys can relate to me." In this way, across multiple years, an enacting of critical listening and storying in the ongoing work of the research team provided opportunities to engage broader meanings of what the work of educational 
research may be.

\section{Quilt Panel 3: Enacting Heart-Engaged Research That Cultivates Fam}

In a caption, Jewel wrote of a Snapchat collage she composed, comprised of cell-phone photographs, text, and emojis: "I made this snap with three friends in high school who I was really close to." She elaborated in a research memo:

They're like home to me. [...] They're my friends, they are people who knew me before I came here, before I began to grow and progress as a person. People change, but your home is an original place of where you come from.

Reflecting across contexts of home and the university campus, Jewel noted in analysis of content and thematic meanings that the Snapshot collage rendered experiences with friends "who I would talk to for a laugh as 'a moment in time."' She recalled connections to "people who knew me before I came here" even as in the context of a university campus she "began to grow and progress." Jewel further explored this unfolding of self across contexts of home and the PwI in a caption accompanying another Snapchat collage. She wrote:

This collage [...] reflects identity in a way of a person who comes to find themselves, and to be comfortable in many different ways: racially, gendered, and religiously. And how, as time passed, from the beginning of freshman year to the end, things had grown in those areas [...] due to me having a safe haven of people, as well as a safe place, to find my acceptance.

Jewel extends broader considerations of identity as unfolded across college orientation and transition experiences, and longtime friendships. As she reflected in a research memo,

Across my first year in college, I constructed a multifaceted understanding of identity. I liked it because it was a collage of myself, and just growing into my womanhood I would say, [...] and realizing my purpose and realizing who I am and just myself as a whole. Jewel further reflected on taking time to connect across people and contexts:

Because I'm busy all the time with school, it's just like I look back on 
the times that me and them would talk and catch up; this was like a moment we would take time to speak and indulge with one another. This moment of indulgence, what some may point to as self-care (Venzant Chambers \& McCready, 2011), especially for women of Color at a PwI, is a moment of joy and a moment of resistance (Oviatt, Jackson, Byrd, \& Deloach, 2020) underscoring broader relational work of our participatory inquiry as an enacting of critical listening and storying amid experiences of transition.

\section{Quilt Panel 4: Honoring Ever-present Connections of Life}

Sarah reflected on a photograph in a caption in the photovoice project (see Figure 4):

Twilight falls on the light green grass of early spring, in this photograph. The warm beacon of light peeking through the branches of a tree, just beginning to bud conjures images of new life in remembrance of life lost.

Sarah further noted:

This emotion provoking photo is in honor of a young Black man back home, in a nearby Detroit neighborhood, whose life

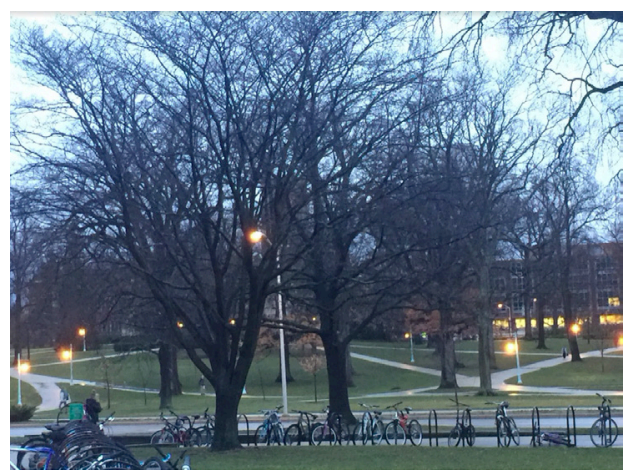

Figure 4. A photovoice photograph taken by Sarah. was taken at a party. [...] For that to happen so close to home and for people being at that party, I realized that there are so many things I can't control. I wanted to take a picture to remember him, and when I thought about my place not only on campus but in life itself, it made me more self aware. You always see stuff happening on the news or on Twitter and when it happens that close.

Sarah, in a research memo, continued "reflections of that period in my first year of my undergraduate experience," noting:

At that time I was thinking of what was available on campus and just 
taking that emotion that was rooted at home and what was available in this space. It made me more socially aware on campus, [...] just recognizing that this space is totally different than high school. Sarah further reflected in a research memo, on the interplay of experiences of transition to the university, and nurturing space for reflection (Morgan et al., 2020):

Being out on campus all day, and coming to see everybody there [our research team meeting], you can just de-stress and talk about your day, the space we've created on Fridays. We've created a space where we can be open and honest about how we feel and what's happening in our lives, it becomes a space where we can say anything. Research-team meetings unfolded as a space of critical listening and storying, prompted by Terry beginning each meeting with the "checkin" (Edwards et al., 2014, p. 433; see also Rust \& Korstange, 2018) that typically unfolded across the first 10 minutes, and also ran longer, the entirety of our research-team meeting following news events such as the results of the 2016 presidential election, or Dr. Christine Blasey Ford's testimony during the fall 2018 nomination of a U.S. Supreme Court justice.

Sarah thus recalled the collective photographs shared across the photovoice project as underscoring broadened notions of place, and community (Shelton \& Thompson, 2020), in experiences of transition of undergraduates of Color to a PwI. She wrote:

Many of the photos that were taken demonstrated themes of emotion, regardless of participant. They didn't just come from school, but they also came from home. When I think of home, I think of family, and this connects on how we as a research group have become a family as well. Emotion is probably the strongest connection that all participants had throughout the photovoice project [and] played a big theme in the pictures that were taken and analyzed. [...] That was the overall feeling that we were trying to get out of this research, how a first-year student feels about transitioning from high school into college.

\section{Quilt Panel 5: Fostering Spaces of Relationality}

Chauntel, following content and thematic analysis of photographs, 
further wrote across such meanings of fostering spaces (Morgan et al., 2020) with undergraduate co-researchers of Color on a PwI:

One of these spaces being the annual Black Power Rally which I was an audience member my first year and a participant second year. This event is put on by the Black Student Alliance in which there is an array of performances and skits put on by the Black students and faculty. Second, the neighborhood I live in is where most of the Black people live on campus. Living there allowed me as a freshman and a sophomore to see Black people in one space having fun and interacting with each other on a daily basis. It is one of the most rewarding feelings to come home after a long day of school and see people who look like you and can relate to you in ways that other can not. Finally, the space that my research team has made has really helped me throughout my journey, because our meetings sometimes do not feel like research meetings. [...] Advice and real life experience are shared collectively.

Contexts of research-team meetings, and undergraduates' writing across captions, research memos, and manuscript drafts thereby carried forward multiple meanings of "politics of place" (Kinloch, 2009, p. 154) as an asserting of literacies of relationality. Chauntel, for example, reflecting across schooling contexts of secondary and higher education, and considering the urgency and possibilities of relationality as critical listening and storying, shared:

Attending a predominantly white high school [...], there were very few people who celebrated being Black as I did, and [...] there was no space made for people of Color to celebrate the culture. The thought of going to a PwI was always one that was very scary because I thought once again I was being robbed of the opportunity to celebrate my culture unlike those who chose to attend Historically Black Colleges and Universities. However, I made it my mission to get involved with the Black community here at the institution we study at. As a result of my high school experience, as a first-year undergraduate student I was determined to not only make new connections with people of Color but also cherish those relationships 
that had already been established.

\section{Implications}

At a time of increasing racial, ethnic, linguistic, and cultural diversity in the U.S., teachers in public schools remain overwhelmingly white, female, monolingual, and upper middle class. This demographic, largely reflected in teacher-education programs grappling with recruiting and retaining preservice teachers of Color, presses us to recognize a shift needed in the work of supporting and sustaining preservice teachers of Color. We offer implications for envisioning participatory spaces for teaching, teacher education, and student affairs research and practice that build and foster experiences extending literacy and learning as relational, underscoring possibilities of critical listening and storying with collaborators.

Duncan-Andrade and Morrell (2008) notably argue for a pedagogy that builds with social contexts of lives of urban youth. Teacher-education, and college orientation, transition, and retention initiatives may similarly consider moving toward paradigms pointing to opportunities for students to attend to their lived experiences as a stance-taking toward justice. We assert this work as moving toward critical scholarship that forwards "radical solidarity" (Oviatt, Jackson, Byrd, \& Deloach, 2020). For example, enacting a model of YPAR in higher education extends opportunities for including first-year students of Color in educational research that provides necessary mentorship, and evokes meanings of community. Moreover, the weaving of experiences of undergraduate co-researchers navigating systemic injustice at a PwI extends possibilities of what it may mean to embolden spaces of heart-held teaching and learning. We understand this quilting as both continuous, and expansive. We highlight the importance of youth and young adult collaboration as an enacting of youth leadership within and beyond schooling or campus contexts. Teachers, teacher educators, educational researchers, and student affairs educators may more closely consider roles of peer collaboration, including how first-year students may be involved in inquiry and the sharing of experiences of transitions. In our work, undergraduate co-researchers took up agentic roles in story collection, asking how narratives of experiences of transition 
of undergraduates to a PwI may be more fully considered (Beras, 2018). Chauntel, reflecting on designing the YPAR inquiry, and gathering, analyzing, and sharing data, wrote:

My hope is that this quilt of thoughts, feelings, experiences, never stops getting bigger. I think this research is not only useful for undergraduate students but anyone who is dealing with a transition from one point in life to another. [...] This research that we are doing is just the beginning of the conversation.

Regina carried forward additional meanings of our inquiry as possibilities of critical listening and storying in the context of college orientation, transition, and retention experiences of undergraduates, writing:

I look at our research kind of like a "resource guide" for future undergraduates of Color. They now have four uniquely different and similar stories in order to make their adjustments as smooth as possible. Our hope is that they will take the pieces from our stories that they need. In a way, we have paved the way for others to expand and build upon this work.

We thus assert possibilities in reframing the teaching, teacher educator, research, and student affairs space to consider and build with knowledges, perspectives, and questions of undergraduate researchers and preservice teachers of Color as integral to their orientation, transition, and retention experiences. We return, then, to gathering that Monday night in September, sharing photographs collected and analyzed in a photovoice project in our YPAR inquiry of experiences of transition to a PWI; this rendering of stories told and yet to be told. 


\section{References}

Amoah, J. (1997). Narrative: The road to black feminist theory. Berkeley Women's LJ, 12, 84.

Anderson, V., McKenzie, M., Allan, S., Hill, T., McLean, S., Kayira, J., Knorr, M., Stone, J., Murphy, J., \& Butcher, K. (2015). Participatory action research as pedagogy: investigating social and ecological justice learning within a teacher education program. Teaching Education, 26(2), 179-195.

Bennett, C. I., McWhorter, L. M., \& Kuykendall, J. A. (2006). Will I ever teach? Latino and African American students' perspectives on PRAXIS I. American Educational Research Journal, 43(3), 531-575.

Barkley Brown, E. B. (1989). African-American women's quilting. Signs: Journal of Women in Culture and Society, 14(4), 921-929.

Bautista, M. A., Bertrand, M., Morrell, E., Scorza, D. A., \& Matthews, C. (2013). Participatory action research and city youth: Methodological insights from the Council of Youth Research. Teachers College Record, 115(10), 1-23.

Beras, K. (2018). Prime time: The first 6 weeks adjusting, belonging, and thriving in college. Journal of College Orientation, Transition, and Retention, 25(2), 127-130.

Cammarota, J. (2008). The cultural organizing of youth ethnographers: Formalizing a praxis-based pedagogy. Anthropology \& Education Quarterly, 39(1), 45-58.

Carey, R. L. (2019). Am I smart enough? Will I make friends? And can I even afford it? Exploring the college-going dilemmas of Black and Latino adolescent boys. American Journal of Education, 125(3), 381415.

Collins, P. H. (2000). Gender, black feminism, and black political economy. The Annals of the American Academy of Political and Social Science, 568(1), 41-53.

Covarrubias, R., Gallimore, R., \& Okagaki, L. (2018). "I know that I should be here": Lessons learned from the first-year performance of borderline university applicants. Journal of College Student Retention: Research, Theory \& Practice, 20(1), 92-115. 
Dingus, J. E. (2008). "I'm learning the trade" mentoring networks of Black women teachers. Urban Education, 43(3), 361-377.

Dozier, V. (2018). If you only know Gregory Eaton as a restaurant owner, you don't know Gregory Eaton. https://www.lansingstatejournal. com/story/news/2018/03/15/gregory-eaton-greg-restaurantlobbyist-lansing-gregorys-garage/344807002/

Duncan-Andrade, J. M. R., \& Morrell, E. (2008). The art of critical pedagogy: Possibilities for moving from theory to practice in urban schools (Vol. 285). Peter Lang.

Eberle-Sudre, K., Welch, M., \& Nichols, A. H. (2015). Rising Tide: Do College Grad Rate Gains Benefit All Students?. Education Trust.

Edwards, E., McArthur, S. A., \& Russell-Owens, L. (2016). Relationships, being-ness, and voice: Exploring multiple dimensions of humanizing work with black girls. Equity \& Excellence in Education, 49(4), 428439.

Flennaugh, T. K., Howard, T. C., Malone, M. L., Tunstall, J., Keetin, N., \& Chirapuntu, T. (2017). Authoring student voices on college preparedness: A case study. Equity \& Excellence in Education, 50(2), 209-221.

Freire, P. (2018). Pedagogy of the oppressed. Bloomsbury Publishing USA. Green, E. L. (2019). Flint's children suffer in class years after drinking the lead-poisoned water. https://www.nytimes.com/2019/11/06/us/ politics/flint-michigan-schools.html

Greene, S., Burke, K. J., \& McKenna, M. K. (2018). A review of research connecting digital storytelling, photovoice, and civic engagement. Review of Educational Research, 88(6), 844-878.

Haddix, M., McArthur, S. A., Muhammad, G. E., Price-Dennis, D., \& SealeyRuiz, Y. (2016). At the kitchen table: Black women English educators speaking our truths. English Education, 48(4), 380.

Holsapple, M. A. (2012). Service-learning and student diversity outcomes: Existing evidence and directions for future research. Michigan Journal of Community Service Learning, 18(2), 5-18.

Howard, T. C., Flennaugh, T., \& Tunstall, J. (Eds.). (2016). Expanding college access for urban youth: What schools and colleges can do. New York, 
NY: Teachers College Press.

Johnson, K. L. (2019). “Are You White?” Racial identity formation in Biracial white-Asian women from the United States. [Doctoral dissertation]. George Mason University.

Kinloch, V. (2009). Suspicious spatial distinctions: Literacy research with students across school and community contexts. Written Communication, 26(2), 154-182.

Kinloch, V., \& San Pedro, T. (2014). The space between listening and storying: Foundations for Projects in Humanization (PiH). In D. Paris, \& M. Winn (Eds.), Humanizing research: Decolonizing qualitative inquiry with youth and communities, 21-42. Sage.

Kirkness, V. J., \& Barnhardt, R. (1991). First Nations and higher education: The four R's -Respect, relevance, reciprocity, responsibility. Journal of American Indian Education, 1-15.

Kohli, R. (2009). Critical race reflections: Valuing the experiences of teachers of color in teacher education. Race Ethnicity and Education, 12(2), 235-251.

Kohli, R., \& Pizarro, M. (2016). Fighting to educate our own: Teachers of color, relational accountability, and the struggle for racial justice. Equity \& Excellence in Education, 49(1), 72-84.

Knight, M. G., Marciano, J. E., Wilson, M., Jackson, I., Vernikoff, L., Zuckerman, K. G., \& Watson, V. W. M. (2019). “It's all possible”: Urban educators' perspectives on creating a culturally-relevant, schoolwide, college-going culture for Black and Latino male students. Urban Education, 54(1), 35-64.

Milner, H. R. (2003). Reflection, racial competence, and critical pedagogy: How do we prepare pre-service teachers to pose tough questions?. Race Ethnicity and Education, 6(2), 193-208.

Mirra, N., Filipiak, D., \& Garcia, A. (2015a). Revolutionizing inquiry in urban English classrooms: Pursuing voice and justice through youth participatory action research. English Journal, 49-57.

Mirra, N., Garcia, A., \& Morrell, E. (2015). Doing youth participatory action research: Transforming inquiry with researchers, educators, and students. Routledge. 
Mitchell, T. D., \& Donahue, D. M. (2009). "I do more service in this class than I ever do at my site": Paying attention to the reflections of students of color in service-learning: New solutions for sustaining and improving practic. In J. Strait, \& M. Lima (Eds.), The future of service-learning: New solutions for sustaining and improving practic. Stylus Publishing.

Morgan, K., Lane, T. B., Hutchful, J., Willis, S. Y., \& Clarke Jr., L. (2020). Transitioning, belonging, and the Black student experience: A phenomenological study. Journal of College Orientation, Transition, and Retention, 27(1), 1 - 27.

Oviatt, R. L., Jackson, S., Byrd, C., \& Deloach, R. (2020). Moments of joy and resistance: Crossroads praxis as critical mentorship [Unpublished manuscript]. Department of Teacher Education, Michigan State University.

Oviatt, R. L., Watson, V. W., \& Flennaugh, T. K. (2020). Negotiated questioning with undergraduate co-researchers in a youth participatory action research collaborative [Unpublished manuscript]. Department of Teacher Education, Michigan State University. Park, J. J., Denson, N., \& Bowman, N. A. (2013). Does socioeconomic diversity make a difference? Examining the effects of racial and socioeconomic diversity on the campus climate for diversity. American Educational Research Journal, 50(3), 466-496.

Paris, D., \& Alim, H. S. (Eds.). (2017). Culturally sustaining pedagogies: Teaching and learning for justice in a changing world. New York, NY: Teachers College Press.

Ray, J. L., \& Smith, A. D. (2012). Using photographs to research organizations: Evidence, considerations, and application in a field study. Organizational Research Methods, 15(2), 288-315.

Ringgold, F. (1996). Tar beach. New York, NY: Dragonfly Books / Penguin Random House.

Roegman, R., Knight, M., Taylor, A., \& Watson, V. W. M. (2016). From microscope to mirror: Doctoral students' evolving positionalities through engagement with culturally sensitive research. International Journal of Qualitative Studies in Education, 29(1), 44-65. 
Rogers-Ard, R., Knaus, C. B., Epstein, K. K., \& Mayfield, K. (2013). Racial diversity sounds nice; Systems transformation? Not so much:

Developing urban teachers of color. Urban Education, 48(3), 451-479.

Rust, D. Z., \& Korstange, R. (2018). Prioritizing Reflection and Integrative Learning in First-Year Seminar Courses. Journal of College Orientation, Transition, and Retention, 25(2).

Saldaña, J. (2015). The coding manual for qualitative researchers. Thousand Oaks, CA: Sage.

San Pedro, T., Carlos, E., \& Mburu, J. (2017). Critical listening and storying:

Fostering respect for difference and action within and beyond a

Native American literature classroom. Urban Education, 52(5), 667-693.

Sensoy, O., \& DiAngelo, R. (2017). Is everyone really equal?: An introduction to key concepts in social justice education. Teachers College Press.

Shelton, L., \& Thompson, C. (2020). Fostering resilience for Puerto Rican college students in transition after Hurricane Maria. Journal of College Orientation, Transition, and Retention, 27(1), 1-29.

Soep, E. (2006). Critique: Assessment and the production of learning. Teachers College Record, 108(4), 748.

Solorzano, D., Ceja, M., \& Yosso, T. (2000). Critical race theory, racial microaggressions, and campus racial climate: The experiences of African American college students. Journal of Negro Education, 60-73. Venzant Chambers, T. T., \& McCready, L. T. (2011). "Making space" for ourselves: African American student responses to their marginalization. Urban Education, 46(6), 1352-1378.

Villaseñor, M. J., Reyes, M. E., \& Muñoz, I. (2013). Mujerista Mentoring for Chicanas/Latinas in Higher Education. Journal of College Student Retention: Research, Theory \& Practice, 15(1), 49-64.

Watson, V. W. M., \& Beymer, A. (2019). Praisesongs of place: Youth envisioning space and place in a literacy-and-songwriting initiative. Research in the Teaching of English, 53(4), 297-319.

Watson, V. W. M., \& Knight-Manuel, M. G. (2020). Humanizing the Black immigrant body: Envisioning Diaspora literacies of youth and young adults from West African countries. Teachers College Record, 122(13). 
Watson, V. W. M., \& Knight-Manuel, M. G. (2017). Challenging popularized narratives of immigrant youth from West Africa: Examining social processes of navigating identities and engaging civically. Review of Research in Education, 41(1), 279-310.

Wilson, S. (2008). Research is ceremony: Indigenous research methods. Fernwood Publishing.

Wissman, K. K., Staples, J. M., Vasudevan, L., \& Nichols, R. E. (2015). Cultivating research pedagogies with adolescents: Created spaces, engaged participation, and embodied inquiry. Anthropology \& Education Quarterly, 46(2), 186-197.

Yao, C. W., Rutt, J. N., Briscoe, K., Kirshenbaum, A., Knight, M. W., \& Buell, K. J. (2019). Navigating the first year: Transition and Adjustment experiences of international students of color at a predominantly white institution. Journal of College Orientation, Transition, and Retention, 26(2).

YPAR Hub. (2015). What is YPAR? http://yparhub.berkeley.edu/ 